\title{
Knowledge, attitude and practice regarding breast cancer and breast self-examination among a sample of the educated population in Iraq
}

\author{
N.A.S. Alwan, ${ }^{1,2}$ W.M. Al-Attar, ${ }^{1}$ R.A. Eliessa, ${ }^{1}$ Z.A. Madfaie ${ }^{7}$ and F.N. Tawfeeq
}

$$
\begin{aligned}
& \text { المعارف والمو اقف والممارسات حول سرطان الثدي والفحص الذاتي للثدي لدئ لدى عينة من المثقفات في العراق }
\end{aligned}
$$

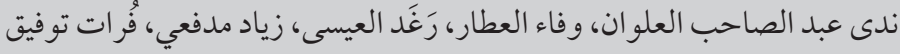

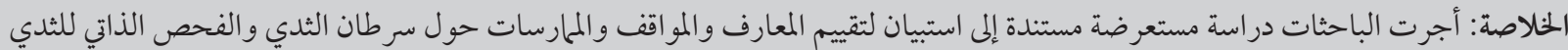

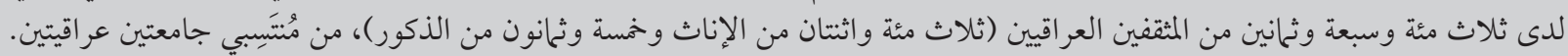

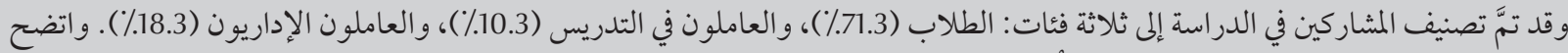

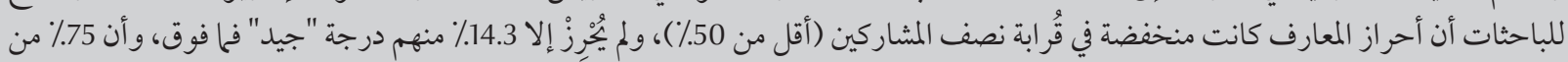

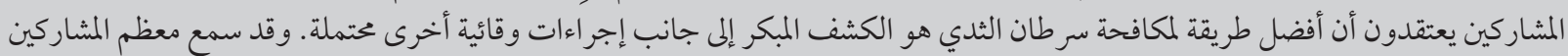

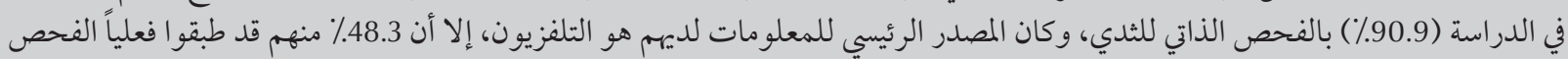

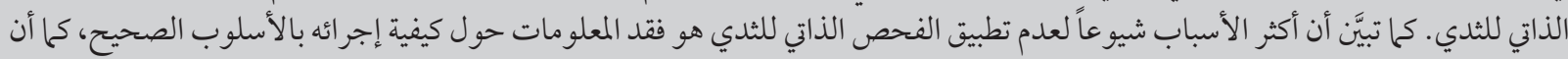

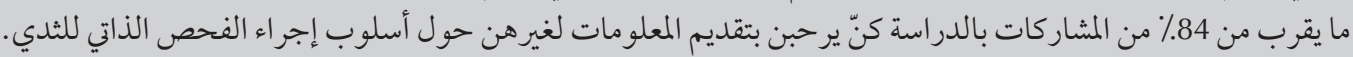

ABSTRACT This cross-sectional, questionnaire-based study evaluated the knowledge, attitude and practice towards breast cancer and breast self-examination (BSE) among 387 (302 females and 85 males) educated Iraqis affiliated to 2 Iraqi universities. The participants were categorized into 3 occupations: student (71.3\%), teaching staff $(10.3 \%)$ and administrative staff $(18.3 \%)$. About half of the participants had a low knowledge score $(<50 \%)$; only $14.3 \%$ were graded as "Good" and above. Almost $75 \%$ of the participants believed that the best way to control breast cancer was through early detection and other possible preventive measures. Most participants $(90.9 \%)$ had heard of BSE, the main source of information being television. However, only $48.3 \%$ practised BSE; the most common reason for not doing so was lack of knowledge of how to perform the technique correctly. Almost $84 \%$ of the female participants were willing to instruct others in the technique of BSE.

Connaissances, attitudes et pratiques en matière de cancer du sein et d'auto-examen des seins d'un échantillon de la population iraquienne ayant fait des études

RÉSUMÉ La présente étude transversale basée sur un questionnaire a évalué les connaissances et les attitudes en matière de cancer du sein de 387 Iraniens ayant fait des études (302 femmes et 85 hommes) et travaillant ou étudiant dans deux universités iraquiennes, ainsi que les pratiques des femmes de l'échantillon en matière d'autoexamen des seins. Les participants ont été répartis en trois groupes : les étudiants $(71,3 \%)$, les enseignants $(10,3 \%)$ et le personnel administratif $(18,3 \%)$. Les résultats de près de la moitié des participants étaient faibles en termes de connaissances $(<50 \%)$ : seuls $14,3 \%$ ont obtenu des résultats « satisfaisants » ou supérieurs. Près de $75 \%$ des participants pensaient que la meilleure méthode pour lutter contre le cancer du sein était une détection précoce et l'adoption d'autres mesures préventives. La majorité des participants $(90,9 \%)$ avaient entendu parler de l'autoexamen des seins, la télévision étant leur principale source d'information. Toutefois, seules $48,3 \%$ des femmes pratiquaient l'auto-examen des seins ; la raison invoquée le plus fréquemment était l'absence de connaissances permettant d'utiliser la technique correctement. Près de $84 \%$ des participantes étaient volontaires pour former les autres à la technique de l'auto-examen des seins. 


\section{Introduction}

Globally, breast cancer is the most common cancer among women, comprising $23 \%$ of the female cancers. It is also the leading cause of cancer-related deaths in low-resource countries [1,2]. Although substantial improvement in survival from this disease has been reported in high-income countries, the risk continues to increase and survival rates in middle-and low-income countries remain low [1]. It has been predicted that the largest increase in cancer incidence within the next 15 years worldwide is likely to be in the Eastern Mediterranean Region (EMR), where breast cancer is reported as the commonest type of female malignancy in almost all national cancer registries $[1,3]$.

In Iraq, breast cancer ranks the first among the commonest malignancies among all the population and accounts for approximately one-third of the registered female cancers according to the latest Iraqi Cancer Registry which shows a trend for the disease to affect younger women [4]. The expanding burden of breast cancer in the EMR in general, and Iraq in particular, emphasizes the urgent need to establish comprehensive national cancer control programmes. Of the recorded approaches to breast cancer control, as proposed by the World Health Organization (WHO), early detection and screening offer the most immediate hope for a reduction in related mortality [5]. Thus in 2009 a "National Breast Cancer Early Detection and Research Program" was established in Iraq whose main objectives include: providing diagnostic services, enhancing knowledge and skills of health personnel, promoting relevant studies, and raising the awareness of the general population to the common risk factors and means for early detection of the disease, with focus on mammography, physical breast examination (PBE) and breast self-examination (BSE). During 2010-2011 numerous health education symposiums were carried out at various universities, ministries and provinces in Iraq, as essential component of a public awareness campaign.

The main aim of this study, which is based on data collected from 2 breast cancer symposiums, was to determine the knowledge of, attitude to and practice of breast cancer and BSE among a sample of the educated population affiliated to 2 large universities in Iraq.

\section{Methods}

The study was conducted during October 2010 by the Breast Cancer Research Unit of Baghdad Medical College under the authority of the Iraqi National Breast Cancer Research Program of the Ministry of Higher Education and Scientific Research.

Data were collected from participants attending 2 separate symposiums conducted at Al-Mystansireya and AlKufa Universities that were organized as part of the national awareness campaign. The total number of participants recruited for the study was 387 (302 females and 85 males) with an age range of 18-63 years. The participants were categorized into 3 groups according to their occupation: student $(n=276$; $71.3 \%)$, teaching staff $(n=40 ; 10.3 \%)$ and administrative staff of the universities $(n=71 ; 18.3 \%)$. Each participant was asked to complete a pre-coded standardized questionnaire prepared by the researchers to elicit sociodemographic information, and knowledge, attitudes and practice towards breast cancer and BSE.

The first part of the questionnaire comprised the following 20 questions that assessed knowledge of the common risk factors for breast cancer, the possible means for prevention and the recommended screening methods.

- Q1: Breast cancer ranks the first according to the latest Iraqi Cancer Registry among the general population and among women.
- Q2: Breast cancer is the commonest cancer among women worldwide.

- Q3: The tools that are utilized for early detection of breast cancer include mammography, ultrasound, PBE and BSE

- Q4: The best time and frequency to conduct BSE in premenopausal women is after the menstrual period every month.

- Q5: The best time and frequency to conduct BSE after menopause is any specific day every month.

- Q6: Growing older increases the probability of developing breast cancer in women.

- Q7: Nulliparity increases the probability of developing breast cancer in women.

- Q8: Late menopause (over 55 years) increases the probability of developing breast cancer.

- Q9: Early menarche (under 11 years) increases the probability of developing breast cancer.

- Q10: Oopherectomy (surgical excision of the ovaries) decreases the probability of developing breast cancer.

- Q11: Postmenopausal obesity increases the probability of developing breast cancer.

- Q12: Oral contraceptive pills and hormone replacement therapy could increase the probability of developing breast cancer when used for more than 5 years.

- Q13: Alcohol consumption could increase the probability of developing breast cancer in women.

- Q14: Exposure to radiation at a young age (adolescence and early adulthood) in females could increase the probability of developing breast cancer.

- Q15: Treatments for breast cancer include surgery, chemotherapy, radiotherapy and hormonal manipulation. 
- Q16: The best approach to breast cancer control could be achieved through early detection.

- Q17: The main reason behind the increase in the probability of developing breast cancer in postmenopausal obese women is elevation in the level of endogenous estrogens.

- Q18: Preventive measures against breast cancer include alcohol abstinence, promoting physical activity, healthy diet, maintaining ideal body weight and avoiding unprescribed hormonal therapy.

- Q19: Low levels of endogenous estrogen decrease the probability of developing breast cancer in women.

- Q20: Factors that could decrease the incidence of breast cancer include early pregnancy, seeking medical advice for apparent breast lumps, physical activity, avoiding a fat-rich diet and performing periodic regular breast examinations.

A positive answer was assigned 1 point, whereas a wrong answer was given zero. The results were calculated as frequencies of the correct answers out of the total answers of the same question.

Question 21 asked specifically about knowledge, attitude and practice regarding BSE, namely: knowledge of BSE and source of knowledge; practice ofBSEand reasons why not; willingness to instruct others in BSE and reasons why not. The willingness of the participants to join the Iraqi National Breast Cancer Awareness Program was also determined.

Data were analysed by using the SPSS, version 14. Frequencies, means and standard deviations were tabulated and association between variables was measured with the chi-squared test. The association was considered statistically significant when $P$ was $<0.05$.

\section{Results}

Table 1 summarizes the frequencies of the correct answers for each question. There was a significant difference between the 3 groups $(P<0.05)$ in their knowledge elicited in questions $1,3,7$, $10,11,18$ and 19. In general, the answers for questions 1, 7, 10 and 11 were more accurately interpreted by the teaching staff, while the answers of the students were superior for questions 3, 18 and 19. Approximately three-quarters of the study sample were aware that the best way to control breast cancer was through early detection and other possible preventive measures (questions 16 and 18). On the other hand, more than $70 \%$ failed to understand the relationship between endogenous estrogen excess and the risk of the disease (questions 10 and 19).

Overall, $71 \%$ of the participants were not aware that breast cancer is the commonest malignancy among the Iraqi population and 56\% did not know that it ranks the first cancer among women worldwide. Only 44.8\% knew that mammography, ultrasound, PBE and BSE are used in early detection of breast cancer. While $66.9 \%$ of the study sample knew the correct time and frequency to perform BSE before menopause, only $33.7 \%$ knew this for postmenopausal women, although $61.9 \%$ were aware that the risk increases as women grow older. A large proportion, 44.7\%, 49.3\% and $71.4 \%$ respectively, did not know that nulliparity, late menopause and early menarche are other important risk factors. Only 17\% were aware that early oophorectomy could have a protective role and $37.4 \%$ that hormonal intake could increase the risk. Although 66.9\% believed that postmenopausal obesity could be a risk factor, only $39.9 \%$ and $29.4 \%$ respectively attributed that to elevation in the level of endogenous estrogens and knew that maintaining low levels of these hormones could decrease the risk. About $72 \%$ of the participants did not know that exposure to radiation at a young age could increase the risk of breast cancer in females. The majority of the participants, $74.2 \%$, believed that the best way to control breast cancer was through early detection and $72.2 \%$ were able to identify other preventive measures that included alcohol abstinence, physical activity, healthy diet, maintaining a healthy body weight and avoiding unprescribed hormonal therapy.

Table 2 shows that knowledge about breast cancer was poor in about half of the sample (a score $<50 \%$ ). Overall, $85.7 \%$ of the answers were scored as less than "good" (i.e. < 70\%). There was a highly significant difference in the mean scores of the 3 occupational groups: teaching staff had the highest mean score [52.75 (SD 23.66)], while administrative staff the lowest $[42.24$ (SD 20.31)] $(P=0.0002)$.

Table 3 shows that $90.9 \%$ had heard about BSE and the main source of knowledge was television (55.9\%), followed by doctors (21.5\%). A significantly greater proportion of teaching staff and students obtained their information on BSE from television than administrative staff $(P=0.013)$.

Only 138 of the female participants (48.3\%) practised BSE (Table 4). Of the $51.7 \%$ who did not, the reasons why they did not were not knowing the correct technique (43.2\%) and not trusting their own examination (33.1\%); only $7.4 \%$ did not believe in the benefit of BSE (9.3\% of students, 3.1\% of administrative staff and none of the teaching staff). There was a significant difference between the 3 groups regarding being afraid to perform BSE; only $7.5 \%$ of the students were afraid compared to $27.3 \%$ and $25.0 \%$ of the teaching staff and administrative staff respectively $(P=0.015)$.

Alarge proportion of the female participants (229/274, 83.6\%) indicated they would be willing to instruct others in the technique (Table 5), and $42 \%$ of these expressed a keen interest to join the Iraqi National Breast Cancer Awareness Program. Of the $16.5 \%$ not willing to instruct others in BSE, the reasons given included lack of time (37.8\%) and lack of interest (24.4\%); the difference was significant between the occupation groups for lack of interest $(P<0.048)$. 


\begin{tabular}{|c|c|c|c|c|c|c|}
\hline \multirow[t]{2}{*}{ Q \# } & Statements on breast cancer & & Occupation & & & $P$-value \\
\hline & & $\begin{array}{l}\text { Administrative } \\
\text { No. }^{a} / \text { No. }^{\mathrm{b}}(\%)\end{array}$ & $\begin{array}{c}\text { Teaching } \\
\text { No. }^{\mathrm{a}} / \text { No. }^{\mathrm{b}}(\%)\end{array}$ & $\begin{array}{c}\text { Student } \\
\text { No. }{ }^{\mathrm{a} / \text { No. }}{ }^{\mathrm{b}}(\%)\end{array}$ & $\begin{array}{c}\text { Total } \\
\text { No. }{ }^{\text {a }}{ }^{\text {No. }}{ }^{\mathrm{b}}(\%)\end{array}$ & \\
\hline 1 & $\begin{array}{l}\text { Breast cancer ranks the first in } \\
\text { Iraq }\end{array}$ & $26 / 65(40.0)$ & 18/38 (47.4) & $64 / 269(23.8)$ & 108/372 (29.0) & 0.001 \\
\hline 2 & $\begin{array}{l}\text { Breast cancer is the commonest } \\
\text { cancer in women worldwide }\end{array}$ & $31 / 65(47.7)$ & 18/39 (46.2) & $117 / 272(43)$ & $166 / 376(44.1)$ & 0.152 \\
\hline 3 & $\begin{array}{l}\text { Mammography, ultrasound, } \\
\text { PBE and BSE are used for early } \\
\text { detection }\end{array}$ & $25 / 68(36.8)$ & $15 / 39(38.5)$ & $126 / 272(46.3)$ & $166 / 379(43.8)$ & 0.002 \\
\hline 4 & $\begin{array}{l}\text { In premenopausal women it is } \\
\text { best to conduct BSE monthly, } \\
\text { after the menstrual period }\end{array}$ & $43 / 67(64.2)$ & $27 / 38(71.1)$ & $175 / 261(67.0)$ & $245 / 366(66.9)$ & 0.732 \\
\hline 5 & $\begin{array}{l}\text { In postmenopausal women it is } \\
\text { best to conduct BSE on a fixed } \\
\text { day each month }\end{array}$ & $28 / 69(40.6)$ & $16 / 38(42.1)$ & $79 / 258(30.6)$ & $123 / 365(33.7)$ & 0.530 \\
\hline 6 & Age increases the risk in women & $37 / 68(54.4)$ & 28/39 (71.8) & $167 / 268(62.3)$ & 232/375 (61.9) & 0.182 \\
\hline 7 & $\begin{array}{l}\text { Nulliparity increases the risk in } \\
\text { women }\end{array}$ & $33 / 67(49.3)$ & $27 / 39(69.2)$ & $148 / 270(54.8)$ & 208/376 (55.3) & $<0.001$ \\
\hline 8 & $\begin{array}{l}\text { Late menopause (over } 55 \text { years) } \\
\text { increases the risk }\end{array}$ & $30 / 65(46.2)$ & 20/38 (52.6) & $136 / 264(51.5)$ & $186 / 367(50.7)$ & 0.522 \\
\hline 9 & $\begin{array}{l}\text { Early menarche (under } 11 \text { years) } \\
\text { increases the risk }\end{array}$ & $12 / 64(18.8)$ & $18 / 39(46.2)$ & $75 / 264(28.4)$ & 105/367 (28.6) & 0.202 \\
\hline 10 & $\begin{array}{l}\text { Oopherectomy decreases the } \\
\text { risk }\end{array}$ & 7/64 (10.9) & $18 / 39(46.2)$ & $37 / 261(14.2)$ & $62 / 364(17.0)$ & $<0.001$ \\
\hline 11 & $\begin{array}{l}\text { Postmenopausal obesity } \\
\text { increases the risk }\end{array}$ & $36 / 62(58.1)$ & 29/39 (74.4) & $180 / 265(67.9)$ & $245 / 366(66.9)$ & 0.042 \\
\hline 12 & $\begin{array}{l}\text { Oral contraceptive pills and } \\
\text { HRT may increase the risk if } \\
\text { used for }>5 \text { years }\end{array}$ & $25 / 64(39.1)$ & $15 / 37(40.5)$ & $95 / 266$ (36.5) & 135/361 (37.4) & 0.851 \\
\hline 13 & $\begin{array}{l}\text { Alcohol consumption may } \\
\text { increase the risk in women }\end{array}$ & $41 / 63(65.1)$ & 26/38 (68.4) & $200 / 270(74.1)$ & $267 / 371(72.0)$ & 0.606 \\
\hline 14 & $\begin{array}{l}\text { Exposure to radiation at a young } \\
\text { age in females may increase } \\
\text { the risk }\end{array}$ & 21/63 (33.3) & 10/38 (26.3) & $72 / 266(27.1)$ & $103 / 367(28.1)$ & 0.657 \\
\hline 15 & $\begin{array}{l}\text { Treatments for breast cancer } \\
\text { include surgery, chemotherapy, } \\
\text { radiotherapy and hormonal } \\
\text { manipulation }\end{array}$ & 39/63 (61.9) & $25 / 39(64.1)$ & $163 / 269(60.6)$ & $227 / 371$ (61.2) & 0.370 \\
\hline 16 & $\begin{array}{l}\text { Early detection is the best } \\
\text { approach to breast cancer } \\
\text { control }\end{array}$ & $51 / 363(81.0)$ & $27 / 38(71.1)$ & 195/267 (73.0) & $273 / 368(74.2)$ & 0.933 \\
\hline 17 & $\begin{array}{l}\text { The increased risk in } \\
\text { postmenopausal obese } \\
\text { women is mainly due to raised } \\
\text { endogenous estrogen levels }\end{array}$ & $20 / 57(35.1)$ & 17/32 (53.1) & $97 / 247$ (39.3) & 134/336 (39.9) & 0.055 \\
\hline 18 & $\begin{array}{l}\text { Preventive measures include } \\
\text { alcohol abstinence, physical } \\
\text { activity, healthy diet and } \\
\text { body weight, avoidance of } \\
\text { unprescribed hormonal therapy }\end{array}$ & $35 / 56(62.5)$ & $24 / 38(63.2)$ & $201 / 266(75.6)$ & $260 / 360(72.2)$ & 0.025 \\
\hline
\end{tabular}




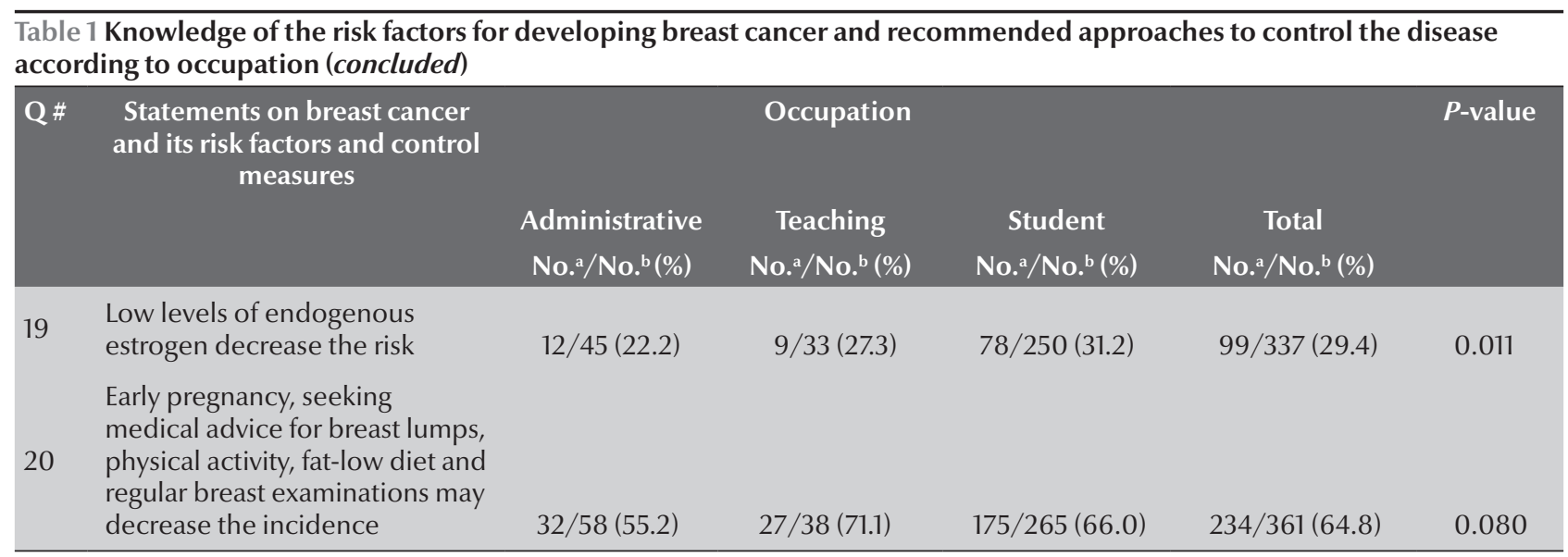

${ }^{a}$ Number of correct answers to the question.

${ }^{b}$ Number of participants who answered the question.

'Adolescence and early adulthood.

$P B E=$ physical breast examination; $B S E=$ breast self-examination; $H R T=$ hormone replacement therapy

\section{Discussion}

Our study found that knowledge about breast cancer was poor in about half of the targeted educated population; $51.2 \%$ scored less than $50 \%$ of correct answers. Only $15 \%$ of the answers were graded as "Good" and over with a highly significant difference between the 3 study groups, the best score being achieved by the teaching staff. Our results showed that $71 \%$ and $56 \%$ respectively were not aware that breast cancer is the commonest malignancy among the Iraqi population and that it is the commonest cancer among women worldwide. While almost three-quarters of the study population answered that the best way to control breast cancer was through early detection and other preventive measures, only $43.8 \%$ knew that mammography, ultrasound, PBE and BSE are used as screening tools. It was interesting to note that $91.5 \%$ had already heard about BSE but only about $67 \%$ and $34 \%$ knew the correct frequency and timing of performing BSE before and after menopause respectively.

Studies conducted in EMR report differing results regarding knowledge about breast cancer and BSE. Only a few reported correct information on the frequency and timing of BSE indicating low rates of practice. In a study from Saudi Arabia where knowledge, attitude and practices were evaluated among female school teachers, only $12 \%$ had a high score; the rest of the participants were categorized as a having limited level [6]. Our respondents had better knowledge of risk factors for breast cancer; $61 \%$ knew that ageing increased the risk of breast cancer while only $3 \%$ in the Saudi study knew the effect of ageing. None of the Saudi Arabian respondents linked age at menarche or menopause to an increased risk of the disease but in our study $28.6 \%$ and $50.7 \%$ respectively recognized the association. Another study carried out among female secondary-school students in Jeddah demonstrated that the level of knowledge of the risk factors of breast cancer was very low; $80 \%$ failed to

\begin{tabular}{|c|c|c|c|c|}
\hline \multirow[t]{2}{*}{ Score level } & \multicolumn{3}{|c|}{ Occupation } & \multirow[b]{2}{*}{$\begin{array}{c}\text { Total } \\
(n=385) \\
\text { No. }(\%)\end{array}$} \\
\hline & $\begin{array}{c}\text { Administrative } \\
\left(\begin{array}{c}\left(n=69^{\mathrm{a}}\right) \\
\text { No. }(\%)\end{array}\right.\end{array}$ & $\begin{array}{l}\text { Teaching } \\
(n=40) \\
\text { No. }(\%)\end{array}$ & $\begin{array}{c}\text { Student } \\
(n=276) \\
\text { No. }(\%)\end{array}$ & \\
\hline Poor $(<50 \%)$ & $40(58.0)$ & $17(42.5)$ & $140(50.7)$ & $197(51.2)$ \\
\hline Just passed (50\%-59\%) & $11(15.9)$ & $5(12.5)$ & $61(22.1)$ & $77(20.0)$ \\
\hline Fair (60\%-69\%) & $12(17.4)$ & $4(10.0)$ & $40(14.5)$ & $56(14.5)$ \\
\hline Good (70\%-79\%) & $4(5.8)$ & $6(15.0)$ & $28(10.1)$ & $38(9.9)$ \\
\hline Very good $(80 \%-89 \%)$ & $2(2.9)$ & $7(17.5)$ & $7(2.5)$ & $16(4.2)$ \\
\hline Excellent $(90 \%-100 \%)$ & $0(0.0)$ & $1(2.5)$ & $0(0.0)$ & $1(0.3)$ \\
\hline Mean (SD) score ${ }^{b}$ & $42.2(20.3)$ & $52.8(23.7)$ & $47.2(16.6)$ & $46.9(18.3)$ \\
\hline
\end{tabular}

${ }^{a}$ Two questionnaires were discarded due to incorrect completion.

${ }^{b} P=0.0002$

$S D=$ standard deviation 


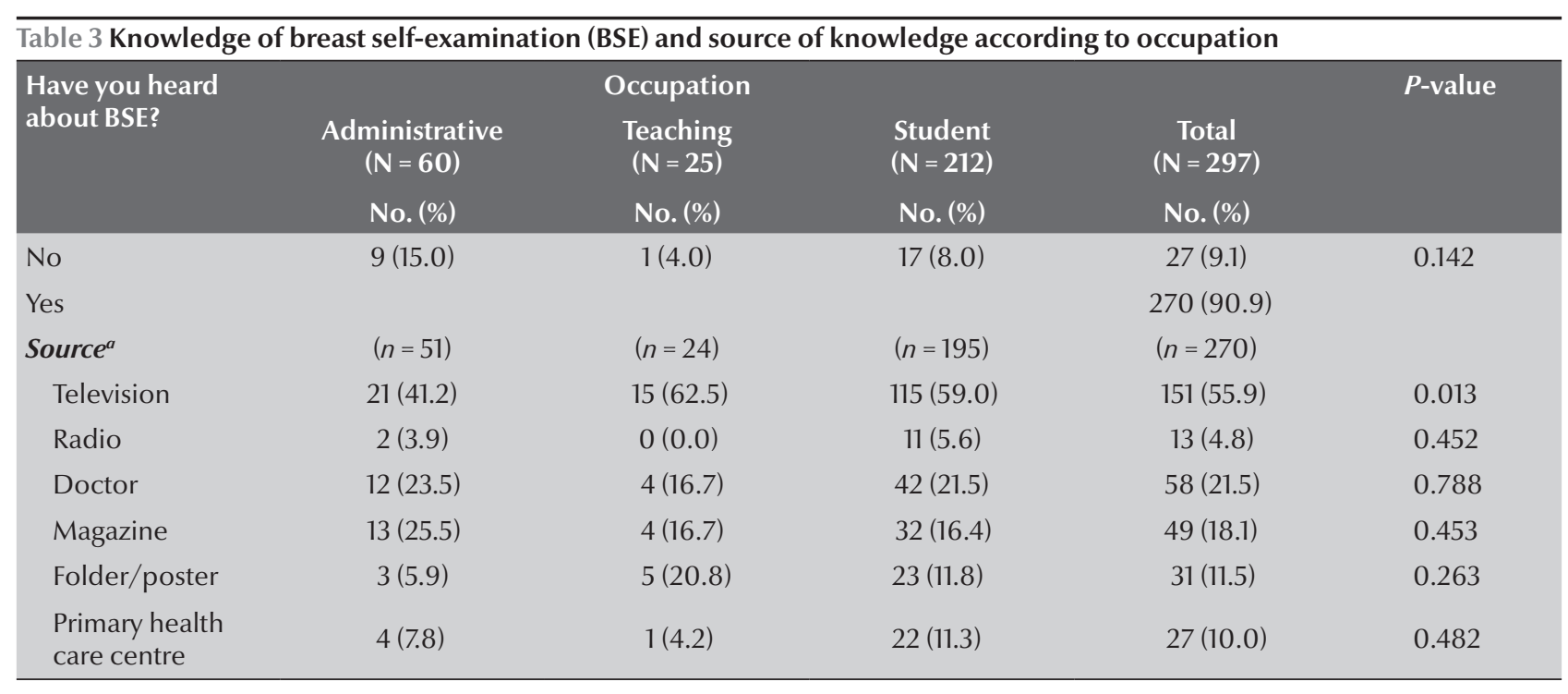

a Participants could give more than one source.

$N=$ total number of women who answered the question

$n=$ number of women who know about BSE and answered the question on source of knowledge.

answer $50 \%$ of the questions correctly [7]. Only 39.6\% reported ever hearing of BSE and a mere $14 \%$ and $7 \%$ respectively knew its correct frequency and timing. However, $82.4 \%$ had a positive attitude towards learning BSE. A more recent survey in Saudi Arabia again emphasized the limited knowledge and practice among female Saudi Arabian students in schools and colleges [8].

A Jordanian study conducted among 163 nurses and 178 teachers showed that profession, age and family history significantly influenced breast cancer awareness [9]. Most of the nurses (88.3\%) were able to correctly answer the questions; the mean awareness score for nurses was higher than that for teachers. A similar study among female health care workers in Tehran demonstrated that their knowledge was unsatisfactory and concluded that Iranian women needed more education about breast cancer [10]. That finding was endorsed by another survey from the IslamicRepublic ofIran [11]. On the other hand, in a teaching hospital in Karachi, 35\% of Pakistani nurses had fairly good level of knowledge about breast cancer risk factors [12]. In Turkey, it was observed that the knowledge increased and the perceived health beliefs improved among university students after peer and group education [13]. Thus knowledge about breast cancer varies considerably in the region among health care workers emphasizing the need for health education.

The main source of knowledge about breast cancer and BSE in our study was the television; particularly among teaching staff and students emphasizing the potential effectiveness of the visual media in modifying health behaviour and promoting education

\begin{tabular}{|c|c|c|c|c|c|}
\hline \multirow{3}{*}{$\begin{array}{l}\text { Do you examine your breasts } \\
\text { periodically }\end{array}$} & \multicolumn{4}{|c|}{ Occupation } & \multirow[t]{3}{*}{$P$-value } \\
\hline & $\begin{array}{l}\text { Administrative } \\
\qquad(\mathbf{N}=58)\end{array}$ & $\begin{array}{l}\text { Teaching } \\
(\mathbf{N}=\mathbf{2 6})\end{array}$ & $\begin{array}{l}\text { Student } \\
(\mathbf{N}=202)\end{array}$ & $\begin{array}{c}\text { Total } \\
(\mathbf{N}=\mathbf{2 8 6})\end{array}$ & \\
\hline & No. (\%) & No. (\%) & No. $(\%)$ & No. (\%) & \\
\hline Yes & $27(46.6)$ & $15(57.7)$ & $96(47.5)$ & $138(48.3)$ & \multirow{3}{*}{0.624} \\
\hline No & & & & $148(51.7)$ & \\
\hline Why not ${ }^{a}$ & $(n=31)$ & $(n=11)$ & $(n=106)$ & $(n=148)$ & \\
\hline Afraid of finding a lump & $8(25.8)$ & $3(27.3)$ & $8(7.5)$ & 19 (12.8) & 0.015 \\
\hline I don't know the technique & $13(41.9)$ & $5(45.5)$ & $46(43.4)$ & $64(43.2)$ & 0.451 \\
\hline I don't trust my examination & $8(25.8)$ & $2(18.2)$ & $39(36.8)$ & $49(33.1)$ & 0.034 \\
\hline I don't think it is of benefit & $1(3.2)$ & $0(0)$ & $10(9.4)$ & $11(7.4)$ & 0.317 \\
\hline
\end{tabular}

a Participants could give more than one reason.

$N=$ total number of participants who answered the question.

$n=$ number of participants who did not practise BSE and answered the question on their reasons why not. 


\begin{tabular}{|c|c|c|c|c|c|}
\hline \multirow{3}{*}{$\begin{array}{l}\text { Would you instruct } \\
\text { others in BSE? }\end{array}$} & \multicolumn{3}{|c|}{ Occupation group } & \multirow[t]{2}{*}{ Total $(\mathbf{N}=274)$} & \multirow[t]{3}{*}{$P$-value } \\
\hline & $\begin{array}{l}\text { Administrative } \\
\qquad(\mathbf{N}=56)\end{array}$ & $\begin{array}{l}\text { Teaching } \\
(\mathbf{N}=23)\end{array}$ & $\begin{array}{l}\text { Student } \\
(\mathbf{N}=195)\end{array}$ & & \\
\hline & No. (\%) & No. (\%) & No. (\%) & No. (\%) & \\
\hline Yes & $47(83.9)$ & $20(87.0)$ & $162(83.1)$ & $229(83.6)$ & \multirow{3}{*}{0.964} \\
\hline No & - & - & - & 45 (16.4) & \\
\hline Why not ${ }^{b}$ & $(n=9)$ & $(n=3)$ & $(n=33)$ & $(n=45)$ & \\
\hline I'm not interested & $0(0.0)$ & $2(66.7)$ & $9(27.3)$ & $11(24.4)$ & 0.048 \\
\hline I don't have time & $2(22.2)$ & $0(0.0)$ & $15(45.5)$ & $17(37.8)$ & 0.251 \\
\hline Other & $7(77.8)$ & $1(33.3)$ & 15 (45.5) & $23(51.1)$ & 0.117 \\
\hline
\end{tabular}

alfyou knew the correct technique.

bParticipants could give more than one reason

$N=$ total number of participants who answered the question.

$n=$ number of participants who would not instruct other on BSE and answered the question on their reasons why not.

among the general population. Other studies from developing societies have reported that television and radio are the most popular media and can reach a wide audience $[6,14-16]$. A study among female medical students in $\mathrm{Ni}$ geria reported that $97.3 \%$ were aware of BSE mainly through television/radio [15], while in another survey from the same country the electronic media were found to be the major resource among female secondary-school teachers [16]. However, the print medium has been found to be commonest source of information in other studies [6]. This emphasizes that source of information varies by setting, which needs to be considered when promoting health education. In our survey, the print medium (journals/ magazines and folders/posters) was the second most common source of information (29.6\% of participants). That may be attributed to the fact that circulation of folders and posters on BSE and publication of cancer-related articles in Iraq were increased a few years ago after initiating the National Program for Early Detection and Research of Breast Cancer. Only about one-fifth of the female participants learned about BSE from doctors. Although the vital role of health-care professionals in promoting public awareness about breast cancer has been illustrated in reports from neighbouring countries [14], often the involvement of the medical profession in community education remains relatively limited in the developing world $[6,16]$.

Although the vast majority of the participants in our study had heard of BSE, less than half practised it. Of those who did not practise BSE, close to half did not do so because they did not know how to. Lack of knowledge of BSE has been identified in earlier studies $[6,7,11]$ and a cross-sectional study on 300 Saudi Arabian females in Qassim region revealed that $69 \%$ had never heard of BSE [17]; of those who had, only $19.7 \%$ reported that they had ever performed BSE and $57 \%$ of those had performed it in the last 12 months. Among women in the United Arab Emirates (UAE), only 14\% had had a PBE and only $13 \%$ performed BSE regularly [18]. This is comparable to what was observed in a study from the Islamic Republic of Iran which found that only $13.4 \%$ of women respondents practised BSE regularly; the most common reason for not performing BSE was lack of knowledge [11]. In a survey involving nurses in 3 large cities in Jordan, $85 \%$ reported performing BSE in the past 12 months but only $17.7 \%$ reported practising the technique on a monthly basis [19]. However, another recent report conducted in Al-Karak Medical Hospital in South Jordan reported that knowledge about BSE was fairly good; $91.4 \%$ of the women had heard of BSE, $73.5 \%$ and $71 \%$ respectively were aware of the correct timing and frequency and $39 \%$ practised BSE monthly [20].

Lack of regular BSE is not confined to EMR. A survey involving 57 South Asian women aged $\geq 40$ years living in the United Kingdom found that only $12 \%$ practised BSE monthly [21]. Similarly, among 124 Chinese women in Hong Kong, less than half practised BSE and only $16 \%$ performed the examination routinely [22]. On the other hand, a report involving 194 Asian Indian women living in the United States found that $40.7 \%$ had performed BSE within the previous month [23]. These frequencies are significantly lower than those reported in other surveys from developed countries $[24,25]$ where BSE practice appears to be correlated with the higher level of education and health care services offered in those regions as compared to the developing world. This may suggest that Asian women living in the West may have limited levels of knowledge about breast cancer and its screening practices.

The reasons given by the participants for never having performed BSE were that they had not been taught the proper technique (43.2\%), that they did not have confidence in their own examination (33.1\%) and fear of detecting 
a lump (12.8\%). The last reason was more often cited by the teaching staff and administrative staff than the students. This is not surprising as $62 \%$ of the study participants believed that age was a risk factor for breast cancer in women. Similar reasons were given in other reports from the region for not practising BSE [10,11,19,26]. Among our female participants, $9.4 \%$ and $3.2 \%$ of university students and administrative staff respectively did not believe in the benefits of BSE. That highlights the urgent necessity of promoting public awareness campaigns in our society on the significance of early detection of breast cancer and BSE.

Interestingly $83.6 \%$ of the Iraqi female participants would be willing to instruct others in BSE; $42 \%$ of whom expressed a keen interest to join the Iraqi National Breast Cancer Awareness Campaign. Interest in BSE has been reported in other regional studies $[18,26]$. In addition in UAE $90 \%$ of nurses had a positive attitude to providing knowledge on the risk factors of breast cancer and about $83 \%$ reported that they had taught BSE to others [27]. A positive attitude towards practicing BSE and promoting health education was more frequently exhibited by younger women $[7,15]$. Of the $16.4 \%$ of our sample who were not interested in teaching BSE, lack of time was the main reason particularly among students (45.5\%).

Given that breast cancer is the commonest cancer in Iraq and that, as in other EMR countries, many patients are still diagnosed at advanced stages
$[28,29]$ resulting in higher mortality rates [1], early detection and screening is pivotal to reducing breast cancer mortality. The obvious lack of knowledge among an educated strata of Iraqi society highlights the urgent need to disseminate information about breast cancer and its risk factors and BSE among the general population, and to educate health personnel. Although controversy exists over the effectiveness of BSE in reducing mortality from breast cancer [30], it is a culturally sensitive and inexpensive technique that remains important in countries with limited resources [2]. Until circumstances allow for routine mammography screening in Iraq, emphasis should be directed to encouraging women to practise $\mathrm{PBE}$ and BSE.

\section{References}

1. International Agency for Research on Cancer. Globocan 2008 Lyon, IARC Press, 2010.

2. Anderson BO et al. Guideline implementation for breast healthcare in low-income and middle-income countries. Overview of the Breast Health Global Initiative Global Summit, 2007. Cancer, 2008, 113(Suppl.):2221-2243.

3. Rastogi T, Hildesheim A, Sinha R. Opportunities for cancer epidemiology in developing countries. Nature Reviews. Cancer, 2004, 4:909-917.

4. Iraqi Cancer Board. Iraqi Cancer Registry 2008. Baghdad, Ministry of Health, 2010

5. Towards a strategy for cancer control in the Eastern Mediterranean Region, 1st ed. Cairo, World Health Organization Regional Office for the Eastern Mediterranean, 2010.

6. Dandash KF, Al-Mohaimeed A. Knowledge, Attitudes, and Practices Surrounding Breast Cancer and Screening in Female Teachers of Buraidah, Saudi Arabia. International Journal of Health Sciences, 2007, 1:61-71.

7. Milaat WA. Knowledge of secondary school students on breast cancer and BSE in Jeddah, Saudi Arabia. Eastern Mediterranean Health Journal, 2000, 6:338-343.

8. Sait $\mathrm{W}$ et al. The knowledge of breast cancer among Saudi females. Saudi Medical Journal, 2010, 31:1242-1244.

9. Madanat H, Merrill RM. Breast cancer risk factors and screening awareness among women nurses and teachers in Amman, Jordan. Cancer Nursing, 2002, 25:276-282.

10. Haji-Mahmoodi M et al. BSE knowledge, attitude and practice among female health care workers in Tehran, Iran. Breast Journal, 2002, 8:222-225.

11. Parsa P, Kandiah M. Breast cancer knowledge, perception and breast self-examination practices among Iranian women. International Medical Journal, 2005, 4:17-24.

12. Ahmed $\mathrm{F}$ et al. Breast cancer risk factors knowledge among nurses in teaching hospitals of Karachi, Pakistan. BMC Nursing, 2006, 5:233-239.
13. Karayort O, Dicle A, Malak AT: Effects of peer and group education on knowledge, beliefs and BSE practice among University students in Turkey. Turkish Journal of Medical Sciences, 2009, 39(1):59-66.

14. Dündar PE et al. The knowledge and attitudes of breast selfexamination and mammography in a group of women in a rural area in western Turkey. BMC Cancer, 2006, 6:43.

15. Irurhe NK et al. Knowledge, attitudes and practices of BSE among female medical students in the University of Lagos. The Internet Journal of Health, 2011, 12(1).

16. Kayode FO, Akande TM, Osagbemi GK. Knowledge, attitude and practice of BSE among female secondary school teachers in Ilorin, Nigeria. European Journal of Scientific Research, 2005, 10(3):2-48

17. Jahan S, Al-Saiqul AM, Abdelgadir MH. Breast cancer knowledge, attitude and practices of breast self examination among women in Qassim region of Saudia Arabia. Saudi Medical Journal, 2006, 27:1737-1741.

18. Bener A et al. Knowledge, attitudes and practices related to breast cancer screening: a survey of Arabic women. Journal of Cancer Education, 2001, 16:215-220.

19. Alkhasawneh I, Akhu-Zaheya I, Suleiman S. Jordanian nurses' knowledge and practice of breast self-examination. Journal of Advanced Nursing, 2009, 65:412-416.

20. Jaradeen N. Breast Cancer Risk-Factors and Breast Self Examination Practice among Jordanian Women. Bahrain Medical Bulletin, 2010, 32:1-7.

21. Choudhry UK, Srivastava R, Fitch MI. Breast cancer detection practices of South Asia women: knowledge, attitude, and beliefs. Oncology Nursing Forum, 1998, 25:1693-1701.

22. Fung SY. Factors associated with breast self-examination behavior among Chinese Women in Hong Kong. Patient Education and Counseling, 1998, 33:233-243.

23. Sadler G, Dhanjal S, Shah R. Asian Indian women: knowledge, attitudes and behaviors toward breast cancer ear- 
ly detection. Public Health Nursing (Boston, Mass.), 2001, 18:357-363.

24. Hackshaw AK, Paul EA. Breast self-examination and death from breast cancer: A meta-analysis. British Journal of Cancer, 2003, 88:1047-1053.

25. Choultara Z et al. Practice of and attitudes toward breast self-examination (BSE): a cross-cultural comparison between younger women in Scotland and Greece. Health Care for Women International, 2004, 24:311-333.

26. Seif N, Aziz M. Effect of Breast Self Examination Training Program on Knowledge, Attitude and Practice of a Group of Working Women. Journal of the Egyptian National Cancer Institute, 2000, 12:105-115.
27. Muttappallymyalil J et al. Attitude and practice of nurses in imparting knowledge on BSE to women in Ajman, United Arab Emirates. Iran Journal of Cancer Prevention, 2010, 3:139144.

28. Alwan N. Breast Cancer: Demographic Characteristics and Clinico-pathological Presentation of Patients in Iraq. Eastern Mediterranean Health Journal, 2010, 16:1073-1078.

29. Alwan N. DNA proliferative index as a marker in Iraqi aneuploid mammary carcinoma. Eastern Mediterranean Health Journal, 2000, 6:1062-1072.

30. Thomas DB et al. Randomized trial of breast self-examination in Shanghai: final results. Journal of the National Cancer Institute, 2002, 94:1445-1457.

\section{Breast cancer guidelines}

Breast cancer remains a common and frequently fatal disease, the most commonly diagnosed cancer in women and the second leading cause of cancer death in the Eastern Mediterranean Region. Studies have shown that most patients with breast cancer in the Eastern Mediterranean Region present for the first time at stages two and three, indicating the need for increased community awareness and early detection of the disease. Well conceived and well managed national cancer control programmes are able to lower cancer incidence and improve the lives of people living with cancer. Guidelines for the early detection and screening of breast cancer, Guidelines for the early detection and screening of breast cancer: quick reference guide and Guidelines for management of breast cancer are evidence-based guidelines designed to support ministries of health in their policy-setting for early detection and screening of breast cancer, as well as to assist health care providers and patients in decision-making in the most commonly encountered situations.

These publications are freely available online and can be accessed through: http:/ /www.emro.who.int/publications/ 